\title{
Effect of Ethanoic Leaf Extracts of Carica Papaya and New Bouldia Laevis on Lipid Profile of Diabetic Wistar Rats
}

\author{
Njoku-Oji, Njideka Nancy ${ }^{1}$; Ifegwu, Njoku Oji ${ }^{2}$; Igbonaju, Marvelous ${ }^{3}$; Okwuonu, Ifeoma Frances ${ }^{4}$; Chukwukaeme, \\ Chidinma Winifred ${ }^{5}$; Mmaju, Chidinma Ifeyinwa ${ }^{6}$; Okonudo, Peter Osezele ${ }^{7}$ \\ ${ }_{1,3,4,5,6,7}$ Department of Human Physiology, Faculty of Basic Medical Sciences, Nnamdi Azikiwe University, Nnewi Campus, \\ Anambra State, Nigeria. \\ ${ }^{2}$ Department of Anatomy, College of Medicine and Health Sciences, Abia State University Uturu, Abia State, Nigeria \\ *Corresponding Author: Ifegwu, Njoku Oji.
}

\begin{abstract}
Objective: This study was carried out to investigate the effect of the ethanolic leaf extracts of Carica papaya $(C$. papaya) and Newbouldia laevis (N. laevis) on the lipid profile of alloxan-induced Wistar rats.

Methodology: Forty (40) male wistar rats weighing 130-150g were procured and acclimatized for two weeks, after which they were divided into eight (8) groups of five (5) rats each, and were housed in cages. The groups were designated as groups A, B, C, D, E, F, G and H. Groups B - H were induced with diabetes using alloxan. Group A served as the control group and received only distilled water; group B diabetic received only distilled water only, while groups $\mathrm{C}-\mathrm{H}$ diabetic received $400 \mathrm{mg} / \mathrm{kg}$ of $C$. papaya, $600 \mathrm{mg} / \mathrm{kg}$ of C. papaya, $400 \mathrm{mg} / \mathrm{kg}$ of $N$. laevis, $600 \mathrm{mg} / \mathrm{kg}$ of $N$. laevis, $200 \mathrm{mg} / \mathrm{kg}$ of $C$. papaya $+200 \mathrm{mg} / \mathrm{kg}$ of $N$. laevis and $300 \mathrm{mg} / \mathrm{kg}$ of $C$. papaya $+300 \mathrm{mg} / \mathrm{kg}$ of $N$. laevis respectively for 21 days through oral route with the aid of oral gastric tube. On the $22^{\text {nd }}$ day, the animals were sacrificed by chloroform inhalation, and blood samples were obtained through cardiac puncture for lipid profile parameters' assays. Data obtained were analyzed using SPSS version 25 and $(P<0.05)$ was considered significant.
\end{abstract}

Result: There was significant increase in the plasma total cholesterol, triglycerides, low density lipoprotein (LDL) with a decrease in plasma high density lipoprotein (HDL) of the animals in group B when compared with the control group. These effects were ameliorated in Groups $\mathbf{C}-\mathbf{H}$ that received the variable doses of the ethanolic leaf extracts $C$. papaya and $N$. laevis with more positive effects on the groups that received the combined ethanolic leaf extracts.

Conclusion: The leaf extracts of $C$. papaya and $N$. laevis have ameliorative effects on the lipid profile alloxan-induced diabetic Wistar rats.

Keywords: Carica papaya, Newbouldia laevis, total cholesterol (TC), triglycerides (TG), low density lipoprotein (LDL), high density lipoprotein (HDL)

\section{INTRODUCTION}

A bout 422 million people worldwide have diabetes, the majority living in low-and middle-income countries, and 1.6 million deaths are directly attributed to diabetes each year

${ }^{[1]}$. Both the number of cases and the prevalence of diabetes have been steadily increasing over the past few decades ${ }^{[1]}$. Diabetes is a chronic, metabolic disease characterized by elevated levels of blood glucose (or blood sugar), which leads over time to serious damage to the heart, blood vessels, eyes, kidneys and nerves ${ }^{[1]}$. The most common is type 2 diabetes, usually in adults, which occurs when the body becomes resistant to insulin or does not make enough insulin ${ }^{[1]}$. In the past three decades the prevalence of type 2 diabetes has risen dramatically in countries of all income levels ${ }^{[1]}$. Type 1 diabetes, once known as juvenile diabetes or insulindependent diabetes, is a chronic condition in which the pancreas produces little or no insulin by itself. For people living with diabetes, access to affordable treatment, including insulin, is critical to their survival. There is a globally agreed target to halt the rise in diabetes and obesity by $2025^{[1]}$.

$\mathrm{DM}$ is a major risk factor for coronary artery disease (CAD), stroke, peripheral arterial disease (PAD), cardiomyopathy, diabetic nephropathy, diabetic retinopathy, and central as well as peripheral neuropathy ${ }^{[2,3]}$. Studies have attempted to correlate blood glucose levels with serum lipid profile parameters ${ }^{[4,5]}$, and research findings have showed that it is mainly body fat that is responsible for increase in prevalence of diabetic disease among the body composition components $[6,7$, and 8$]$. Diabetes is characterized by chronic hyperglycemia and disturbances of carbohydrate, lipid and protein metabolism, and widespread lipid abnormalities in the course of diabetes triggered dyslipidemia as hypercholesterolemia, hypertriglyceridemia, elevated LDL and decreased HDL ${ }^{[9]}$. Dyslipidemia is considered to be a risk factor for the development of Type $2 \mathrm{DM}^{[10,11]}$. Diabetic dyslipidaemia comprises of elevated triglyceride levels as well as decreased HDL cholesterol levels ${ }^{[12]}$. LDL cholesterol is quantitatively not significantly different from non-diabetic subjects; however, there is a preponderance of small dense LDL particles with a greater susceptibility to oxidation ${ }^{[12]}$. Epidemiological studies have shown that patients with type-2 diabetes mellitus with no history of cardiovascular disease have the same risk for cardiac events as non-diabetic patients 
with preexisting coronary disease have ${ }^{[12]}$. The increased incidence of cardiovascular disease (CVD) in diabetes, the greater case fatality and 1-year mortality in patients with myocardial infarction strongly suggest that preventive lipid lowering therapy is of great importance ${ }^{[12]}$. Patients with cardiovascular diseases and diabetes mellitus should strictly controlled their lipid profiles to reduce mortality and complications ${ }^{[13]}$. Thus, the basic goal in the treatment of diabetes is to lower blood glucose concentrations to levels that approximate those representing normal range and its maintenance thereof ${ }^{[14]}$. This helps to reduce the progression of the disease process and its complications with emphasis on hypertension control and correction of dyslipidemia ${ }^{[15]}$.

Medicinal plants are plants that possess therapeutic properties or exert beneficial pharmacological effect on the human or animal body ${ }^{[16]}$. Several medicinal plants have been investigated to ameliorate abnormalities in lipid metabolism arising from diabetes metabolic disorder in many institutions located in different regions of the world ${ }^{[17,18]}$. Examples of such medical plants widely used in traditional treatment system iiclude the Carica payaya and the Newbouldia.

Carica papaya is one of the 22 accepted species in the genus Carica of the family Caricaceae that originate in the tropics of the Americas, perhaps from Central America and southern Mexico ${ }^{[19]}$. It is a small, sparsely branched tree, usually with a single stem growing from 5 to $10 \mathrm{~m}$ (16 to $33 \mathrm{ft}$ ) tall, with spirally arranged leaves confined to the top of the trunk [20]. The lower trunk is conspicuously scarred where leaves and fruit are borne, and the leaves are large, $50-70 \mathrm{~cm} \mathrm{(20-28} \mathrm{in)} \mathrm{in} \mathrm{diameter,}$ deeply palmately lobed, with seven lobes ${ }^{[20]}$. In traditional medicine, papaya leaves have been used as a treatment for malaria ${ }^{[21]}$, an abortifacient, a purgative, or smoked to relieve asthma ${ }^{[19]}$. C. papaya leaves reduce symptoms of asthma, worming and dysentery ${ }^{[22,23]}$ and have long been used as remedy for cancer and infectious diseases ${ }^{[23]}$. Its leaf extract accelerates wound healing ${ }^{[24,25]}$, exhibits vasodilating and antioxidant effects, both being associated with cardiovascular risk reduction ${ }^{[22]}$ and useful in the treatment of diabetes in Nigeria ${ }^{26}$. According to Gray et al, ${ }^{[27]}$ the reduced glucose levels in alloxan induced diabetes suggests that Carica papaya leaves might exert insulin-like effect on peripheral tissues by either promoting glucose uptake metabolism. Besides their hypoglycemic properties [25], different parts of $C$. papaya are used in Mexican folk medicine to treat various diseases such as diarrhea, inflammation and diabetes ${ }^{[25,28]}$. C. papaya has also been attributed to the following properties - antioxidant activity, immunomodulatory, hypoglycemia and hypolipidemic ${ }^{[29]}$ and hepatoprotective [30, 31]. C. papaya leaf extract may be beneficial to diabetic patients and helpful in the prevention of diabetic complications by dyslipidemia improvement ${ }^{[32]}$.

Newbouldia laevis is a fast-growing evergreen shrub or small tree that can only reaches a height of 3 - 8 metres in the west of its range, but can attain a height of up to 20 metres in the east ${ }^{[33,34, \text { and } 35]}$. The bole can be up to $90 \mathrm{~cm}$ in diameter, but is usually less ${ }^{[35]}$. N. laevis is a medium sized angiosperm in the Bignoniaceae family and is native to tropical Africa and grows to a height of about $10 \mathrm{~m}$ with a cauliferous habit. It is ever green, though its leaves turn somewhat dark purple during the cold seasons ${ }^{[36]}$, and is popularly known as the tree of life or fertility tree in Nigeria. Its local Nigerian names include Akoko (Yoruba), Aduruku (Hausa), Kontor (Tiv), Ikhimi (Bini), Ogirisi (Igbo) and Ogiriki (Urhobo). It is used in folkloric medicine to treat a number of diseases. Some of which include the following: the leaves and roots are boiled and used to treat earaches, sore foot, chest pain, fever, convulsion and epilepsy in children ${ }^{[35,37]}$ and diarrhea ${ }^{[38]}$. The roots are used to treat arthritis, malaria and general malady and worms ${ }^{[39]}$. The leaves are used as decoction for eye wash in conjunctivitis. The leaves are also used as chieftaincy leaf in Yoruba land ${ }^{[39]}$. The stem bark is used for toothache, febrifuge, stomach and skin infections [35, 39]. Recently, the flowers and leaves have been used in the treatment of diabetes respectively ${ }^{[37,38,40 \text {, and } 41]}$. It is also used to stop vaginal bleeding in threatened abortion ${ }^{[39]}$ and had shown strong antioxidant activity ${ }^{[42]}$. According to Chinyelu et al, ${ }^{[43]} N$. laevis leaf possesses the ability of managing hyperglycemia, improve haematological and biochemical derrangements in alloxan induced-diabetic rats. It can also control muscle wasting and induce adipogenesis ${ }^{43} . N$. laevis leaf and stem have anti-diabetic properties ${ }^{[44]}$. Anaduaka $e t$ $a l,{ }^{[45]}$ reported that the ethanol extracts of the leaves and stem of $N$. laevis possess hepatoprotective properties for curbing oxidative stress complication. Kolawole et al, ${ }^{[40]}$ in their research reported that the ethanolic extract of the leaves of Newbouldia laevis possesses anti-diabetic properties and that it can prevent the complications of diabetes that result from glycation of hemoglobin and lipid peroxidation. The leaf extract of the $N$. laevis was also reported to lower blood glucose level in diabetic rats ${ }^{[38]}$.

Therefore, this research study was carried out to investigate the effect of the ethanolic leaf extracts of $C$. papaya and $N$. laevis on the lipid profile of alloxan-induced Wistar rats since no work has been carried out on this.

\section{MATERIALS AND METHODS}

\subsection{Animal procurement, care and treatment}

Forty (40) male wistar rats weighing between $130 \mathrm{~g}$ to $130 \mathrm{~g}$ were procured and housed at the Animal house of the Department Physiology, Nnamdi Azikiwe University, Nnewi Campus with wire gauze cages in a well-ventilated area. They were fed with standard commercial pellet diet and water $a d$ libitum. There were acclimatized for two weeks before the experiment. Their health statuses were closely monitored before and during the experiment. All procedures were carried out in strict accordance with the Institutional guidelines on the care and use of experimental animals. 


\subsection{Collection, identification and preparation of plant material}

Fresh leaves of C. papaya and N. laevis were harvested from a local settlement in Okofia in Nnewi, Anambra State. The leaves were properly washed with water to remove sand and other impurities, and were authenticated at the herbarium Unit, Botany Department, Nnamdi Azikiwe University, Anambra State. They were air dried and crushed using laboratory blender. Extraction was done using ethanol. The crude ethanol extracts were filtered into a stainless basin with a white cloth and placed in a water bath so as to dry up the ethanol. Then $200 \mathrm{mg}, 300 \mathrm{mg}, 400 \mathrm{mg}$ and $600 \mathrm{mg}$ of these extracts per $\mathrm{kg}$ body weight were dissolved in $100 \mathrm{mls}$ of distilled water and were administered to the animals in each group respectively.

\subsection{Induction of diabetes}

The rats were divided into non-diabetic control group and experimental groups. The baseline blood glucose level of the experimental group to be inducted was determined before the induction of diabetes. The rats were allowed to fast over night prior to injection of alloxan and diabetes was induced by intra-peritoneal administration of $150 \mathrm{mg}$ of alloxan per $\mathrm{kg}$ body weight of rat $\left(150 \mathrm{mg} / \mathrm{kg}\right.$ body weight ${ }^{[46]}$. After the induction, the rats were allowed to have free access to the same feed and water. After 72 hours, blood samples obtained through tail tip puncture of the rats were used to confirm diabetes in the rats by testing for hyperglycemia using Glucometer. Diabetes was confirmed at fasting blood glucose levels greater than $200 \mathrm{mg} / \mathrm{dl}^{[47]}$.

\subsection{Experimental protocol}

The animals were grouped into eight (8) groups of five (5) rats each. Different doses of the leaf extracts were administered via oral route with the aid of oral gastric tube as shown below:

\section{Group A (The Control group) distilled water. \\ Group B \\ (Diabetic group) distilled water.}

Group C

Diabetic $+400 \mathrm{mg} / \mathrm{kg}$ of C. papaya leaf extract.

Group D Diabetic $+400 \mathrm{mg} / \mathrm{kg}$ of $N$. laevis leaf extract.

Group E Diabetic $+600 \mathrm{mg} / \mathrm{kg}$ of C. papya leaf extract.

Group F Diabetic $+600 \mathrm{mg} / \mathrm{kg}$ of $N$. laevis leaf extract

Group G Diabetic $+200 \mathrm{mg} / \mathrm{kg}$ of $C$. papaya + $200 \mathrm{mg} / \mathrm{kg}$ of $N$. laevis leaf extracts.

Group H Diabetic $+300 \mathrm{mg} / \mathrm{kg}$ of C. papaya + $300 \mathrm{mg} / \mathrm{kg}$ of $N$. laevis leaf extracts.

\subsection{Sample collection and analysis}

The extracts were administered for twenty one (21) days. On the $22^{\text {nd }}$ day, the animals were sacrificed by anaestethizing under chloroform vapour and blood samples were collected from each of the rats by cardiac puncture for hormonal assays. Thus serum levels of total cholesterol (TC), triglycerides (TG), high density lipoprotein (HDL) and low density lipoprotein (LDL) were analyzed using Cholestech LDX analyser.

\subsection{Statistical Analysis}

All data were tabulated and statistically analyzed using SPSS version 25.0. Results were expressed as Mean \pm standard error of mean (SEM). Comparative analysis amongst groups was done using one-way analysis of variance (ANOVA). A posthoc analysis using Bonferoni multiple comparative tests was performed to identify significant groups. $\mathrm{P}<0.05$ was taken as statistically significant.

\section{RESULTS}

Table 1: Effect of ethanoic leaf extracts of C. Papaya and N. laevis on the serum level of total cholesterol (TC).

\begin{tabular}{|c|c|c|}
\hline Groups & Dosage of extract & $\begin{array}{c}\text { Total Cholesterol (TC) } \\
(\mathbf{m m o l} / \mathrm{L})\end{array}$ \\
\hline $\mathrm{A}$ & Control (Distilled water) & $2.43 \pm 0.08$ \\
\hline $\mathrm{B}$ & Diabetic (Distilled water) & $3.37 \pm 0.17^{*}$ \\
\hline $\mathrm{C}$ & $400 \mathrm{mg} / \mathrm{kg}$ of C. papaya & $2.87 \pm 0.21$ \\
\hline $\mathrm{D}$ & $400 \mathrm{mg} / \mathrm{kg}$ of N. laevis & $3.00 \pm 0.22$ \\
\hline $\mathrm{E}$ & $600 \mathrm{mg} / \mathrm{kg}$ of C. papaya & $1.45 \pm 0.23^{*}$ \\
\hline $\mathrm{F}$ & $600 \mathrm{mg} / \mathrm{kg}$ of N. laevis & $1.41 \pm 0.23^{*}$ \\
\hline $\mathrm{G}$ & $\begin{array}{c}200 \mathrm{mg} / \mathrm{kg} \text { of } \text { C. papaya }+ \\
200 \mathrm{mg} / \mathrm{kg} \text { N. laevis }\end{array}$ & $1.76 \pm 0.19$ \\
\hline $\mathrm{H}$ & $\begin{array}{r}300 \mathrm{mg} / \mathrm{kg} \text { of } \text { C. papaya }+ \\
300 \mathrm{mg} / \mathrm{kg} \text { N. laevis }\end{array}$ & $0.75 \pm 0.18^{*}$ \\
\hline
\end{tabular}

(Data are presented as mean \pm standard error of mean and values are considered significant at $\mathrm{P}<0.05$, where $*=$ $\mathrm{P}<0.05)$

Result of the table above showed a significant increase $(\mathrm{P}<0.05)$ on the serum level of TC of the animals in group B (diabetic without treatment) when compared with the serum level of TC in group A (Control), and significant decreases $(\mathrm{P}<0.05)$ on the serum level of TC of the animals in groups $\mathrm{E}$, $\mathrm{F}$ and $\mathrm{H}$ that received $600 \mathrm{mg} / \mathrm{kg}$ of $C$. papaya, $600 \mathrm{mg} / \mathrm{kg}$ of $N$. laevis and $300 \mathrm{mg} / \mathrm{kg}$ of C. papaya $+300 \mathrm{mg} / \mathrm{kg}$ of $N$. laevis of the ethanoic leaf extracts respectively when compared with the serum level of TC of the animals in group A (Control). However, there was no significant change $(\mathrm{P}<0.05)$ on the serum level of TC of the animals in groups $\mathrm{C}, \mathrm{D}$ and $\mathrm{G}$ that received $400 \mathrm{mg} / \mathrm{kg}$ of $C$. papaya, $400 \mathrm{mg} / \mathrm{kg}$ of $N$. laevis and $200 \mathrm{mg} / \mathrm{kg}$ of $C$. papaya $+200 \mathrm{mg} / \mathrm{kg} N$. laevis of the ethanoic leaf extracts respectively when compared with the serum level of TC of the animals in group A (Control). 


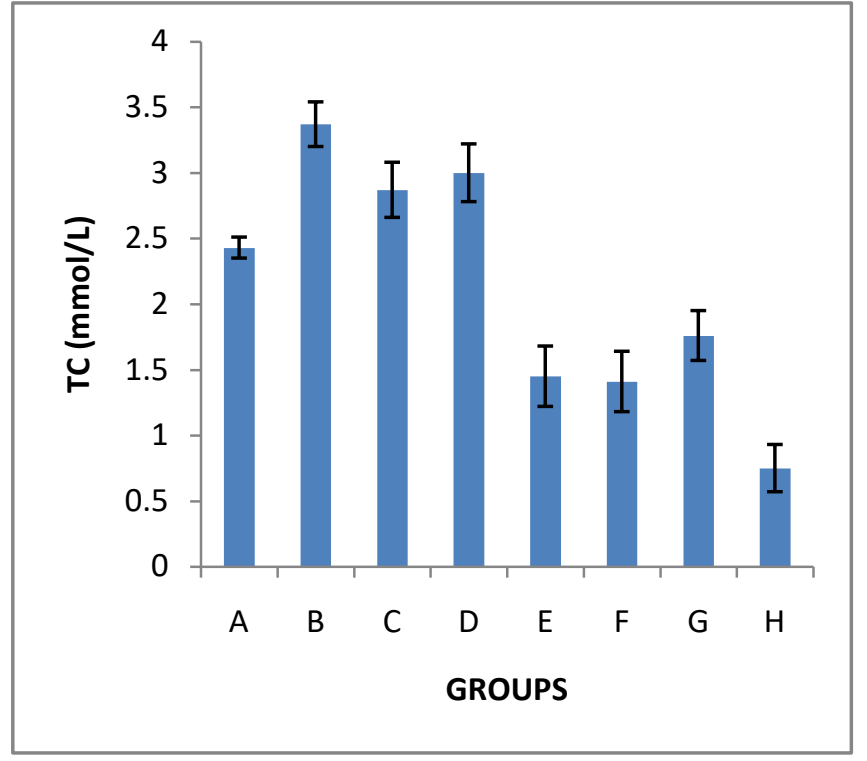

Figure 1: Effect of ethanoic leaf extracts of C. Papaya and N. laevis on the serum level of total cholesterol (TC) of alloxan-induced wistar rat.

Table 2: Effect of ethanoic leaf extracts of C. Papaya and N. laevis on the serum level of Triglyceride (TG)

\begin{tabular}{|c|c|c|}
\hline Groups & Dosage of extract & $\begin{array}{c}\text { Triglyceride (TG) } \\
\text { (mmol/L) }\end{array}$ \\
\hline A & Control (Distilled water) & $0.66 \pm 0.03$ \\
\hline B & Diabetic (Distilled water) & $1.03 \pm 0.08^{*}$ \\
\hline C & $400 \mathrm{mg} / \mathrm{kg}$ of C. papaya & $0.76 \pm 0.03$ \\
\hline $\mathrm{D}$ & $400 \mathrm{mg} / \mathrm{kg}$ of $N$. laevis & $0.72 \pm 0.03$ \\
\hline $\mathrm{E}$ & $600 \mathrm{mg} / \mathrm{kg}$ of C. papaya & $0.41 \pm 0.04^{*}$ \\
\hline $\mathrm{F}$ & $600 \mathrm{mg} / \mathrm{kg}$ of $N$. laevis & $0.42 \pm 0.03^{*}$ \\
\hline $\mathrm{G}$ & $\begin{array}{c}200 \mathrm{mg} / \mathrm{kg} \text { of } C \text {. papaya }+ \\
200 \mathrm{mg} / \mathrm{kg} \text {. laevis }\end{array}$ & $0.52 \pm 0.03$ \\
\hline $\mathrm{H}$ & $\begin{array}{r}300 \mathrm{mg} / \mathrm{kg} \text { of } C \text {. papaya }+ \\
300 \mathrm{mg} / \mathrm{kg} \text {. laevis }\end{array}$ & $0.39 \pm 0.02^{*}$ \\
\hline
\end{tabular}

(Data are presented as mean \pm standard error of mean and values are considered significant at $\mathrm{P}<0.05$, where $*=\mathrm{P}<0.05$ )

Table 2 showed a significant increase $(\mathrm{P}<0.05)$ on the serum level of TG of the animals in group B (diabetic without treatment) when compared with the serum level of TG of the animals in group A (Control), and significant decreases $(\mathrm{P}<0.05)$ on the serum level of TG of the animals in groups $\mathrm{E}$, $\mathrm{F}$ and $\mathrm{H}$ that received $600 \mathrm{mg} / \mathrm{kg}$ of C. papaya, $600 \mathrm{mg} / \mathrm{kg}$ of $N$. laevis and $300 \mathrm{mg} / \mathrm{kg}$ of C. papaya $+300 \mathrm{mg} / \mathrm{kg}$ of $N$. laevis of the ethanoic leaf extracts respectively when compared with the serum level of TG of the animals in group A (Control). However, there was no significant change $(\mathrm{P}<0.05)$ on the serum level of TG of the animals in groups $\mathrm{C}, \mathrm{D}$ and $\mathrm{G}$ that received $400 \mathrm{mg} / \mathrm{kg}$ of $C$. papaya, $400 \mathrm{mg} / \mathrm{kg}$ of $N$. laevis and $200 \mathrm{mg} / \mathrm{kg}$ of C. papaya $+200 \mathrm{mg} / \mathrm{kg} \mathrm{N}$. laevis of the ethanoic leaf extracts respectively when compared with the serum level of TG of the animals in group A (Control).

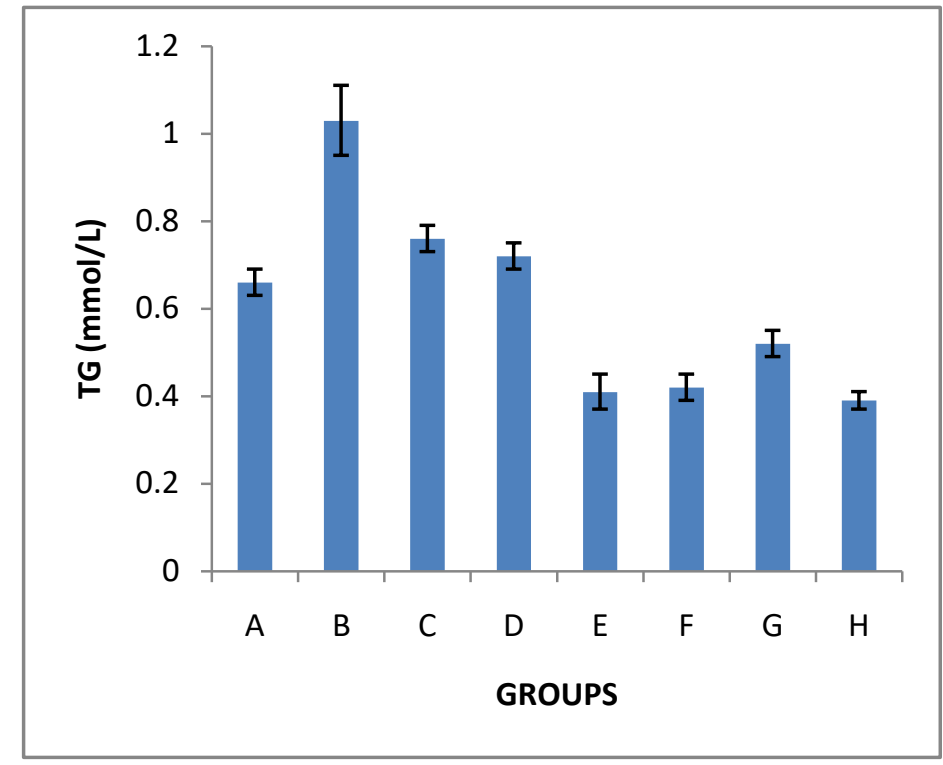

Figure 2: Effect of ethanoic leaf extracts of C. Papaya and N. laevis on the serum level of triglyceride (TG) of alloxan-induced wistar rat.

Table 3: Effect of ethanoic leaf extracts of C. Papaya and N. laevis on the serum level of Low Density Lipoprotein (LDL)

\begin{tabular}{|l|l|l|}
\hline Groups & Dosage of extract & LDL (mmol/L) \\
\hline A & Control (Distilled water) & $1.52 \pm 0.07$ \\
\hline B & Diabetic (Distilled water) & $2.24 \pm 0.17^{*}$ \\
\hline C & $400 \mathrm{mg} / \mathrm{kg}$ of C. papaya & $1.61 \pm 0.04$ \\
\hline D & $400 \mathrm{mg} / \mathrm{kg}$ of $N$. laevis & $1.58 \pm 0.05$ \\
\hline E & $600 \mathrm{mg} / \mathrm{kg}$ of C. papaya & $0.67 \pm 0.17^{*}$ \\
\hline $\mathrm{F}$ & $600 \mathrm{mg} / \mathrm{kg}$ of $N$. laevis & $0.68 \pm 0.16^{*}$ \\
\hline $\mathrm{G}$ & $\begin{array}{l}200 \mathrm{mg} / \mathrm{kg} \text { of } \text { C. papaya }+ \\
200 \mathrm{mg} / \mathrm{kg} \text { N. laevis }\end{array}$ & $1.36 \pm 0.23$ \\
\hline $\mathrm{H}$ & $\begin{array}{l}300 \mathrm{mg} / \mathrm{kg} \text { of } \text { C. papaya }+ \\
300 \mathrm{mg} / \mathrm{kg} \text { N. laevis }\end{array}$ & $0.83 \pm 0.10^{*}$ \\
\hline
\end{tabular}

(Data are presented as mean \pm standard error of mean and values are considered significant at $\mathrm{P}<0.05$, where $*=\mathrm{P}<0.05$ )

Result of Table 3 showed a significant increase $(\mathrm{P}<0.05)$ on the serum level of LDL of the animals in group B (diabetic without treatment) when compared with the serum level of LDL of the animals in group A (Control), and significant decreases $(\mathrm{P}<0.05)$ on the serum level of LDL the animals in groups $\mathrm{E}, \mathrm{F}$ and $\mathrm{H}$ that received $600 \mathrm{mg} / \mathrm{kg}$ of C. papaya, $600 \mathrm{mg} / \mathrm{kg}$ of $N$. laevis and $300 \mathrm{mg} / \mathrm{kg}$ of $C$. papaya + $300 \mathrm{mg} / \mathrm{kg}$ of $N$. laevis of the ethanoic leaf extracts respectively when compared with the serum level of LDL of the animals in group A (Control). However, there was no significant change $(\mathrm{P}<0.05)$ on the serum level of LDL of the animals in groups C, D and $\mathrm{G}$ that received $400 \mathrm{mg} / \mathrm{kg}$ of $C$. papaya, $400 \mathrm{mg} / \mathrm{kg}$ of $N$. laevis and $200 \mathrm{mg} / \mathrm{kg}$ of C. papaya + $200 \mathrm{mg} / \mathrm{kg} N$. laevis of the ethanoic leaf extracts respectively when compared with the serum level of LDL of the animals in group A (Control). 


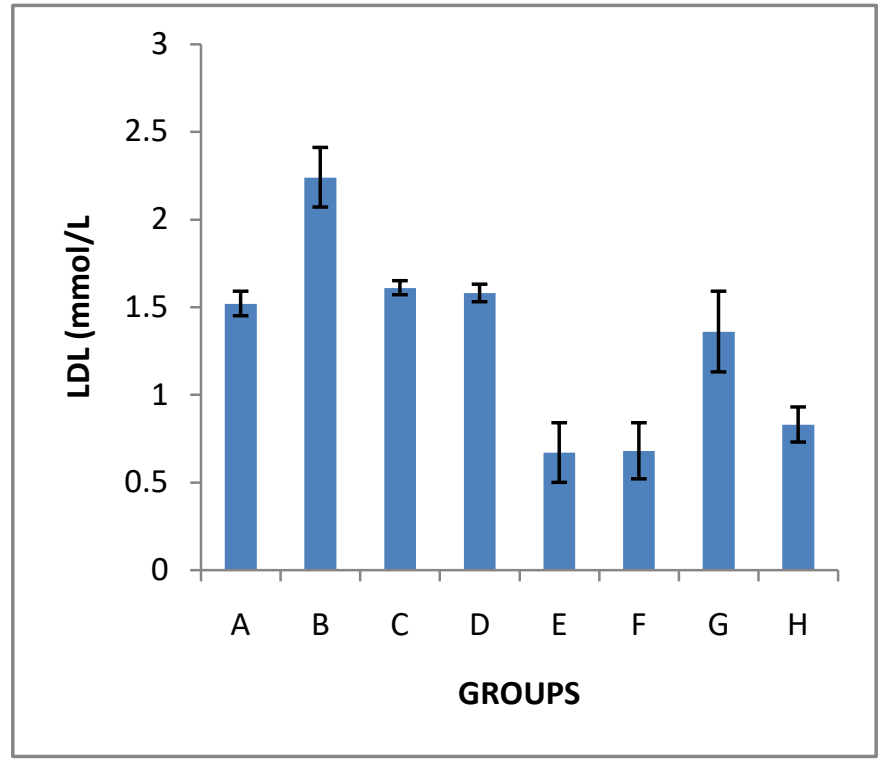

Figure 3: Effect of ethanoic leaf extracts of C. Papaya and N. laevis on the serum level of low density lipoprotein (LDL) of alloxan-induced wistar rat.

Table 4: Effect of ethanoic leaf extracts of C. Papaya and N. laevis on the serum level of High Density Lipoprotein (HDL)

\begin{tabular}{|c|c|c|}
\hline Groups & Dosage of extract & HDL $(\mathbf{m m o l} / \mathbf{L})$ \\
\hline A & Control (Distilled water) & $0.67 \pm 0.03$ \\
\hline B & Diabetic (Distilled water) & $0.33 \pm 0.06^{*}$ \\
\hline C & $400 \mathrm{mg} / \mathrm{kg}$ of C. papaya & $0.65 \pm 0.10$ \\
\hline D & $400 \mathrm{mg} / \mathrm{kg}$ of $N$. laevis & $0.60 \pm 0.04$ \\
\hline $\mathrm{E}$ & $600 \mathrm{mg} / \mathrm{kg}$ of C. papaya & $1.03 \pm 0.11^{*}$ \\
\hline $\mathrm{F}$ & $600 \mathrm{mg} / \mathrm{kg}$ of $N$. laevis & $1.07 \pm 0.11^{*}$ \\
\hline G & $\begin{array}{r}200 \mathrm{mg} / \mathrm{kg} \text { of } \text { C. papaya }+ \\
200 \mathrm{mg} / \mathrm{kg} \text { N. laevis }\end{array}$ & $0.78 \pm 0.03$ \\
\hline H & $\begin{array}{r}300 \mathrm{mg} / \mathrm{kg} \text { of } C \text {. papaya }+ \\
300 \mathrm{mg} / \mathrm{kg} \text { N. laevis }\end{array}$ & $1.05 \pm 0.07^{*}$ \\
\hline
\end{tabular}

(Data are presented as mean \pm standard error of mean and values are considered significant at $\mathrm{P}<0.05$, where $*=\mathrm{P}<0.05$ )

In Table 4 , there was a significant decrease $(\mathrm{P}<0.05)$ on the serum level of HDL of the animals in group B (diabetic without treatment) when compared with the serum level of HDL of the animals in group A (Control), and significant increases $(\mathrm{P}<0.05)$ on the serum level of HDL of the animals in groups $\mathrm{E}, \mathrm{F}$ and $\mathrm{H}$ that received $600 \mathrm{mg} / \mathrm{kg}$ of C. papaya, $600 \mathrm{mg} / \mathrm{kg}$ of $N$. laevis and $300 \mathrm{mg} / \mathrm{kg}$ of C. papaya + $300 \mathrm{mg} / \mathrm{kg}$ of $N$. laevis of the ethanoic leaf extracts respectively when compared with the serum level of HDL of the animals in group A (Control). However, there was no significant change $(\mathrm{P}<0.05)$ on the serum level of HDL of the animals in groups C, D and $\mathrm{G}$ that received $400 \mathrm{mg} / \mathrm{kg}$ of $C$. papaya, $400 \mathrm{mg} / \mathrm{kg}$ of $N$. laevis and $200 \mathrm{mg} / \mathrm{kg}$ of C. papaya + $200 \mathrm{mg} / \mathrm{kg} \mathrm{N}$. laevis of the ethanoic leaf extracts respectively when compared with the serum level of HDL of the animals in group A (Control).

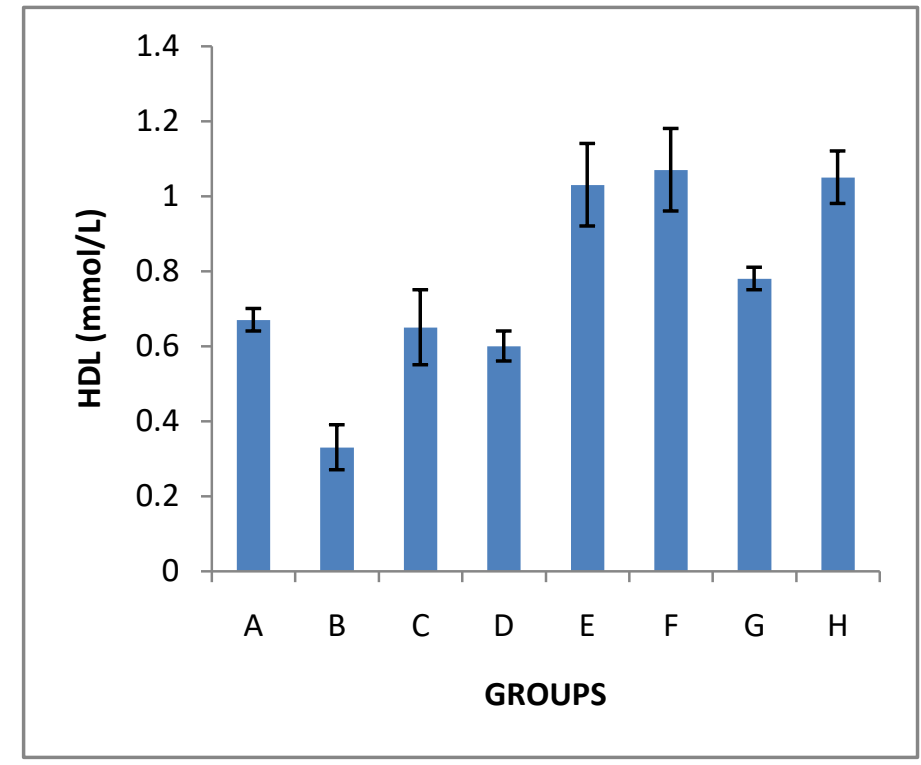

Figure 4: Effect of ethanoic leaf extracts of C. Papaya and N. laevis on the serum level of high density lipoprotein (HDL) of alloxan-induced wistar rat.

\section{DISCUSSION}

According to Aronson and Edelman ${ }^{[48]} \mathrm{DM}$ and its related cardiovascular complications are major public health challenges worldwide, and individuals with type 2 DM have two- to four-fold increased risk of coronary artery disease (CAD), the leading cause of death among people with type 2 DM. Dyslipidemia and hypertension are major modifiable risk factors for T2DM and related CAD, which account for more than $87 \%$ of disability in low- and middle-income countries ${ }^{[49,50]}$, and it has also been revealed that Diabetic dyslipidemia is often characterized by high TC, high TG, low HDL cholesterol, and increased level of $\mathrm{LDL}^{[51,52]}$.

The significant increase $(\mathrm{P}<0.05)$ on the serum level of $\mathrm{TC}$, TG and LDL and significant decrease $(\mathrm{P}<0.05)$ on the serum level of HDL of the animals in group B (diabetic without treatment) in tables 1-4/figures1-4 when compared with the serum level of TC, TG, LDL and HDL in group A (Control) could be due the toxic effect of the induced alloxan on the pancreas leading to diabetes "Diabetic dyslipidemia". Research has shown that alloxan selectively kills the insulinproducing beta-cells found in the pancreas thereby inducing diabetes in laboratory animals ${ }^{[53,54]}$. This occurs most likely because of selective uptake of the compound due to its structural similarity to glucose as well as the beta-cell's highly efficient uptake mechanism (GLUT2). Also alloxan has a high affinity to SH-containing cellular compounds, thus, reduces glutathione content and inhibits glucokinase, a SHcontaining protein essential for insulin secretion induced by glucose ${ }^{[46]}$. Diabetic dyslipidemia has been shown to often been characterized by high TC, high TG, low HDL cholesterol, and increased level of LDL ${ }^{[51,52]}$. Also the increased serum levels of TC, TG, and LDL, and deceased serum level of HDL in group B could be due to inhibitive 
action of insulin due to its deficiency or absence caused by the induced-alloxan to the beta cells of the pancreas. Thus, the hormone-sensitive lipase in adipose tissue which is known to convert triglycerides to free fatty acids and glycerol is inhibited by insulin deficiency leading to increase in serum level of free fatty acids. In the liver, the free fatty acids are catabolized to acetyl $\operatorname{CoA}$, and the excess acetyl CoA is converted to cholesterol, triglyceride and ketone bodies resulting in ketosis ${ }^{[55]}$.

The significant decreases $(\mathrm{P}<0.05)$ on the serum level of $\mathrm{TC}$, TG and LDL, and the significant increases $(\mathrm{P}<0.05)$ on the serum level HDL of the animals in groups $\mathrm{E}, \mathrm{F}$ and $\mathrm{H}$ that received $600 \mathrm{mg} / \mathrm{kg}$ of $C$. papaya, $600 \mathrm{mg} / \mathrm{kg}$ of $N$. laevis and $300 \mathrm{mg} / \mathrm{kg}$ of $C$. papaya $+300 \mathrm{mg} / \mathrm{kg}$ of $N$. laevis of the ethanoic leaf extracts respectively in tables 1- 4/figures 1- 4 when compared with the serum level of TC,TG, LDL and HDL of the animals in group A (Control) could be duo to the anti-diabetic and ameliorating activities of $C$. papaya and $N$. laevis to the diabetic wistar rats at that given dosages. Studies have revealed that $C$. papaya leaf extract accelerates wound healing ${ }^{[24,25]}$, exhibits vasodilating and antioxidant effects, both being associated with cardiovascular risk reduction ${ }^{[22]}$ and treatment of diabetes in Nigeria ${ }^{[26]}$, reduces glucose levels in alloxan induced diabetes ${ }^{[27]}$, exhibits hypoglycemic properties ${ }^{[25]}$, is being used to treat various diseases such as diarrhea, inflammation and diabetes [25, 28], exhibits antioxidant activity, immunomodulatory, hypoglycemia and hypolipidemic ${ }^{[29]}$ and hepatoprotective properties ${ }^{[30,31]}$, may be beneficial to diabetic patients and helpful in the prevention of diabetic complications by dyslipidemia improvement ${ }^{[32]}$. Likewise $N$. laevis leaf has been shown to possess the ability to manage hyperglycemia, improves haematological and biochemical derrangements in alloxan induced-diabetic rats ${ }^{[43]}$, control muscle wasting and induces adipogenesis ${ }^{[43]}$, has anti-diabetic properties [44], possesses hepatoprotective properties for curbing oxidative stress complication [45, 31] possesses anti-diabetic properties and prevents complications of diabetes resulting from glycation of hemoglobin and lipid peroxidation ${ }^{[40]}$ and lowers blood glucose level in diabetic rats ${ }^{[38]}$.

However, the no significant change $(\mathrm{P}<0.05)$ on the serum level of TC, TG, LDL and HDL of the animals in groups C, D and $\mathrm{G}$ that received $400 \mathrm{mg} / \mathrm{kg}$ of $C$. papaya, $400 \mathrm{mg} / \mathrm{kg}$ of $N$. laevis and $200 \mathrm{mg} / \mathrm{kg}$ of C. papaya $+200 \mathrm{mg} / \mathrm{kg} N$. laevis of the ethanoic leaf extracts respectively as shown in tables 1 4/figures 1 - 4 when compared with the serum level of TC, TG, LDL, HDL of the animals in group A (Control) could due because the doses of the leaf extracts administered could not produced significant healing/ameliorative effect when compared to the control group A.

\section{CONCLUSION}

This study has shown that ethanolic leaf extract of $C$. papaya and $N$. laevis extracts have ameliorative effects not just on diabetes mellitus but also on the lipid profile of alloxan- induced diabetic wistar rats. It also confirms that the ameliorative effects are more enhanced in the coadministration of the extracts than in the individual administration. Hence, the combination of the two leaf extracts could be more beneficial in the treatment of diabetes mellitus.

Funding: No funding sources.

Conflict of interest: None declared.

Ethical Approval: Approved by Institutional ethical approval.

\section{REFERENCES}

[1]. World Health Organisation. Diabetes. 2021. https://www.who.int/health-topics/diabetes\#tab=tab_2

[2]. Shaw JE, Sicree RA, Zimmet PZ. Global estimates of the prevalence of diabetes for 2010 and 2030. Diabetes Res Clin Pract. 2010; 87:4-14.

[3]. Grundy SM, Benjamin IJ, Burke GL et al. Diabetes and cardiovascular disease. A statement for healthcare professionals from the American Heart Association. AHA SCIENTIFIC STATEMENT. Circulation 1999; 100:1134-1146.

[4]. Gadi R and Samaha FF: Dyslipidemia in type 2 diabetes mellitus. Curr Diab Rep. 2007, 7 (3): 228-234.

[5]. Khan SR, Ayub N, Nawab S, Shamsi TS: Triglyceride profile in dyslipidaemia of type 2 diabetes mellitus. J Coll Phys Surg Pak. 2008, 18 (5): 270-273.

[6]. Abou-Seif MA and Youssef AA: Evaluation of some biochemical changes in diabetic patients. Clin Chim Acta. 2004, 346: 161-170.

[7]. Elinasri HA and Ahmed AM. Patterns of lipid changes among type 2 diabetes patients in Sudan. East Mediterr Health J. 2008, 14 (2): $314-324$

[8]. Unalacak M, Kara IH, Baltaci D, Ozgur E, Bucaktepe PGE: Effects of Ramadan fasting on biochemical and hematological parameters and cytokines in healthy and obese individuals. Met Synd Rel Disord. 2011, 9 (2): 157-161.

[9]. Ozder, A. Lipid profile abnormalities seen in T2DM patients in primary healthcare in Turkey: a cross-sectional study. Lipids Health Dis 13, 183 (2014). https://doi.org/10.1186/1476-511X-13183.

[10]. Carmena R: Type 2 diabetes, dyslipidemia, and vascular risk: Rationale and evidence for correcting the lipid imbalance. $A m$ Heart J. 2005; 150:859-870.

[11]. Haffner SM, American Diabetes A: Management of dyslipidemia in adults with diabetes. Diabetes Care. 2003;26 Suppl 1:S83-86.

[12]. Georg P and Ludvik B. Lipids and Diabetes. Journal of Clinical and Basic Cardiology 2000; 3 (3), 159-162.

[13]. Basu, A. Role of Berry Bioactive Compounds on Lipids and Lipoproteins in Diabetes and Metabolic Syndrome. Nutrients, 2019; 11, 1983.

[14]. Wadkar KA, Magdum CS, Patil SS, Naikwade NS. Antidiabetic potential of Indian medicinal plants. Journal of Herbal and Medical Toxicology. 2008; 2: 45-50.

[15]. Defronzo RA and Abdul-Ghani M. Type 2 diabetes can be prevented with Early Pharmacological Intervention. Diabetes care. 2011; 34(2): 5202- 5209.

[16]. Natural Products and Drug Discovery. Mdeicinal Plant. ScienceDirect, 2018. https://www.sciencedirect.com/topics/pharmacology-toxicologyand-pharmaceutical-science/medicinal-plant

[17]. Riby, JE. Herbal medicines and phytochemicals of indegenoues plants in California. Berkely Molecular and Pharmarcology Journal, 2006; 69(2): 430-439.

[18]. Ejele AE, Duru IA, Ogukwe CE, Iwu IC. Phytochemistry and antimicrobial potential of basic metabolites of Piper umbellatum, Piper guineense, Ocimum gratissimum and Newbouldia laevis 
extracts, Journal of Emerging Trends in Applied Science, 2012; 3(2): 309-314

[19]. Morton JF (1987). "Papaya". NewCROP, the New Crop Resource Online Program, Center for New Crops \& Plant Products, Purdue University; 1987; 336-346.

[20]. Wikipedia, $\quad$ Papaya. 7021. https://en.wikipedia.org/wiki/Papaya\#cite_note-4

[21]. Titanji VP, Zofou D, Ngemenya MN. "The Antimalaria Potential of Medicinal Plants Used for the Treatment of Malaria in Cameroonian Folk Medicine". African Journal of Traditional, Complementary and Alternative Medicines. 2008; 5 (3): 302-321.

[22]. Runnie I, Salleh MN, Mohamed S, Head RJ, Abeywardena MY. Vasorelaxation induced by common edible tropical plant extracts in isolated rat aorta and mesenteric vascular bed. $J$ Ethnopharmacol. 2004; 92: 311-316.

[23]. Otsuki N, Dang NH, Kumagai E, Kondo A, Iwata S, Morimoto C. Aqueous extract of Carica papaya leaves exhibits anti-tumor activity and immunomodulatory effects. Ethnopharmacol. 2010; 127: 760-767.

[24]. Mahmood T, Rahman MH, Stringam GR, Raney JP, Good AG. Molecular markers for seed colour in Brassica juncea. Genome. 2005; 48: 755-760.

[25]. Corral-Aguayo RD, Yahia EM, Carrillo-López A, GonzálezAguilar G. Correlation between some nutritional components and the total antioxidant capacity measured with six different assays in eight horticultural crops. J Agric Food Chem. 2008; 56: 1049810504.

[26]. Gbolade A A. Inventory of antidiabetic plants in selected districts of Lagos State, Nigeria. J Ethnopharmacol, 2009; 121: 135-139.

[27]. Gray AM, Abdel-Wahab YHA, Flatt PR. The traditional plant treatment, Sabucus nigra (Elder) exhibits insulin-like and insulin releasing actions in vitro, $J$ Nutr, 2000; 130: 15-20.

[28]. Chávez-Quintal P, González-Flores T, Rodríguez-Buenfil I, Gallegos-Tintoré S. Antifungal activity in ethanolic extracts of Carica papaya $L$. cv. Maradol leaves and seeds. Indian $J$ Microbiol. 2011; 51: 54-60.

[29]. Singh VK, Jasiwal P, Kumar P, Single OK. Carica papaya Linn: A potential source for various health problems. Journal of Pharmacy Research, 2010; 3(5): 998 - 1003.

[30]. Ifegwu NO and Anibeze CIP. Effect of ethanolic leaf extracts of Carica papaya and Newbouldia laevis on kidney enzymes of alloxan-induced diabetic wistar rats. EJPMR, 2019; 6(5), 139-144.

[31]. Ifegwu NO, Anibeze CIP, Ndukwe GU, Njoku-Oji NN, Agbai JU, Opara JK, Asebioyo SK. Hepatoprotective potential of ethanolic leaf extracts of Carica papaya and Newbouldia laevis on alloxaninduced diabetic wistar rats. International Journal of Multidisciplinary Research and Development. 2019; 4 (6): 38-42.

[32]. Isela EJ, Carlos AT, Dora EA, Luis FR, Carlos EL, Jorge LB, Leonor L, Juan CD, Deysi YB. Phytochemical screening and hypoglycemic activity of Carica papaya leaf in streptozotocininduced diabetic rats. Rev Bras Farmacogn 2014; 24: 341-347.

[33]. Huxley A. The New RHS Dictionary of Gardening. MacMillan Press, 1992

[34]. Barwick M. Tropical and Subtropical Trees - A Worldwide Encyclopaedic Guide. Thames \& Hudson, London, 2004

[35]. Burkil HM. The Useful Plants of West Tropical. Royal Botanic Gardens; Kew. 1985-2004.

[36]. Okeke AO. Three-minute Herbal Treatment to Reduce Dental Caries with a Newbouldia laevis Based Extract. Am J Undergrad Res. 2003; 2:1-4.

[37]. Tanko Y, Okasha MA, Saleh MI, Mohammed A, Yerima M, Yaro AH, Isa AI. "Antidiabetic Effects of the EthanolicFlower-Extracts of Newbouldia laevis on Blood Glucose Level in StreptozotocinInduced Diabetic Wistar Rats." Medwell Research Journal of Medical Science. 2008; 2 (2): 62-5.
[38]. Owolabi OJ, Amaechina FC, Okoro M. "Effect of ethanol leaf extract of Newbouldia laevis on blood glucose levels in diabetic rats". Tropical Journal of Pharmaceutical Research, 2011; 10(3): 249- 254.

[39]. Nigeria Natural Medicine Development Agency (NNMDA). Medicinal Plant of South-West Zone. Abuja Nigeria: NNMDA Publication, 2006; 1: 26.

[40]. Kolawole OT, Akanji MA, Awe OE, Akiibinu MO. Ethanolic Extract of Leaves of Newbouldia laevis Attenuates Glycosylation of Hemoglobin and Lipid Peroxidation in Diabetic Rats. American Journal of Pharmacology and Toxicology, 2013; 8 (4): 179-186.

[41]. Bosha JA, Asuzu IU, Anaga AO. "Antidiabetic Effects of Newbouldia laevis Methanol Leaf Extract on Alloxan-Induced Diabetic Rats." Presented at the 37th Annual Conference of the West African Society for Pharmacology (WASP) Held at Sheraton Hotel Lagos, Nigeria, 2013; 45.

[42]. Ogunlana OI and Ogunlana OO. "In vitro Assessment of Antioxidant Activity of Newbouldia Laevis." J. Med. Plant Res. 2008; 2 (8): 176-9.

[43]. Chinyelu CO, Peter AA, Chukwuemeka SN. Biochemical and Haematological Effects of the Leaf Extract of Newbouldia laevis in Alloxan-induced Diabetic Rats. Journals of Biomedical \& Life Sciences, 2017; 5 (6):18-36.

[44]. Anaduaka EG, Ogugua VN, Egba S, Apeh VO. Comparative antidiabetic effects of ethanol extract of Newbouldia laevis leaves and stem on serum lipid profile and lipid peroxidation status in alloxan induced diabetic rats. Word J. Pharm. Pharma. Sci. 2013; 2(3):833-845

[45]. Anaduaka EG, Ogugua VN, Agu CV, Okonkwo CC. Ethanol extracts of Newbouldia laevis stem and leaves modulate serum liver marker enzymes and antioxidant enzymes activities in diabetic rats. African Journal of Biotechnology. 2014; 13(22) 2265-2275.

[46]. Szudelski T (2001). The mechanism of Alloxan and Streptozotocin actions in $\beta$-cell of the rats' pancreas. Physiol Res 50(6): 536-546

[47]. Adenowo AF, Ilori MF, Balogun FO, Kazeem MI. Protective effect of ethanol leaf extract of Carica papaya linn (Caricaceae) in alloxan-induced diabetic rats. Tropical Journal of Pharmaceutical Research. 2014; 13(11): 1877-1882.

[48]. Aronson D and Edelman ER. Coronary artery disease and diabetes mellitus. Cardiol. Clin. 2014; 32:439-455.

[49]. Preis SR, Pencina MJ, Hwang SJ, D'Agostino RB, Savage PJ, Levy D, Fox CS. Trends in cardiovascular disease risk factors in individuals with and without diabetes mellitus in the Framingham Heart Study. Circulation. 2009; 120:212-220.

[50]. Yusuf S, Rangarajan S, Teo K, Islam S, Li W, Liu L, Bo J, Lou Q, $\mathrm{Lu} \mathrm{F}$, Liu T, et al. Cardiovascular risk and events in 17 low-, middle-, and high-income countries. N. Engl. J. Med. 2014; 371:818-827.

[51]. Santos-Gallego CG and Rosenson RS. Role of HDL in those with diabetes. Curr Cardiol Rep. 2014; 16(9):512.

[52]. Mooradian AD. Dyslipidemia in type 2 diabetes mellitus. Nat Rev Endocrinol. 2009; 5(3):150-159.

[53]. Danilova I.G., Sarapultsev P.A., Medvedeva S.U., Gette I.F., Bulavintceva T.S., Sarapultsev A.P. "Morphological Restructuring of Myocardium During the Early Phase of Experimental Diabetes Mellitus". Anat. Rec. 2014; 298 (2): $396-$ 407.

[54]. Loreto D and Elina V. Experimental surgical models in the laboratory rat. Boca Raton: CRC Press. 2009.

[55]. Al Shamaony L, Al Khazraji MS, Twaij HA. Hypoglycemic effects of Artemisia herba-alba. II. Effect of a valuable extract on some blood parameters indiabetic animals. J Ethnopharmacol. 1994; 43(3):167-171. 